\title{
Hubungan Antara Persentase Serangan Hama Tikus dengan Produktivitas Lahan Melalui Pendekatan Foto Udara
}

\section{Interact Between Percentage of Rat Pest Attack and Rice Fields Productivity Through the Approach of Aerial Photography}

\author{
Prihandoni Widodo, I Made Anom S. Wijaya, I Putu Gede Budisanjaya \\ Program Studi Teknik Pertanian, Fakultas Teknologi Pertanian, Unud \\ Email :prihandoniw@gmail.com
}

\begin{abstract}
Abstrak
Hama tikus adalah salah satu hama yang dapat merugikan petani. Serangan hama tikus dapat menurunkan hasil panen bahkan dapat mengakibatkan gagal panen. Serangan hama tikus pada tanaman padi akan mempengaruhi produktivitas lahan. Semakin besar persentase serangan hama tikus maka produktivitas lahan akan semakin rendah. Untuk itu penelitian ini bertujuan untuk mengetahui hubungan antara persentase serangan dengan produktivitas lahan. Tahapan - tahapan yang harus dilalui dalam penelitian ini antara lain, pengambilan data, analisis image processing, analisis regresi, validasi dan diakhiri dengan perhitungan akurasi. Pengambilan data dilapangan meliputi akuisisi foto udara dan pengukuran hasil panen. Analisis image processing menggunakan bantuan software Adobe Photoshop CS6 dan software Matlab 2013. Analisis regresi menggunakan bantuan software Microsoft Excel 2013 dengan menggunakan tiga jenis analisis regresi, antara lain : regresi linier, regresi kuadratik, regresi polinomial pangkat 3. Persamaan regresi polinomial pangkat 3 menghasilkan persamaan terbaik. Persamaan polinomian pangkat 3 yang didapat adalah sebagai berikut $y=-1.10^{-6} x^{3}+0,0003 x^{2}-0,0218 x+0,6159$ dengan koefisien determinasi sebesar 0,9645 atau dapat pula diartikan $96,45 \%$ variasi dari variabel terikat dapat dijelaskan oleh variabel bebas. Nilai error yang dimiliki persamaan tersebut adalah $8,17 \%$.
\end{abstract}

Kata kunci : hama padi, tikus sawah, foto udara, persentase serangan, produktivitas

\begin{abstract}
Rats pest is one of the any pests that can harm the farmers. Pest rodent attacks can decrease yields even affect to crop failures. The percentage of rice fields attack will affect the productivity inversed. The bigger percentage of rodent pests, will make the lower rice fields productivity. Therefore, this study aims to determine the relationship between percentage of pest roddents attacks with rice field productivity. Stages that must be passed in this research, among others, data retrieval, image processing analysis, regression analysis, validation and ending with the calculation of accuracy. Field data taking includes the acquisition of aerial photography and measurement of the harvest. Analysis of image processing using Adobe Photoshop CS6 software support and Matlab 2013 software. Regression analysis using Microsoft Excel 2013 software assistance using three types of regression analysis, among others: linear regression, quadratic regression, rank polynomial regression 3. Polynomial regression equation of rank 3 yields the best equation. The polynomial equation of rank 3 obtained as follows $y=-1.10-6 \times 3+0.0003 \times 2-0,0218 x+0,6159$ with a coefficient of determination equal to 0,9645 or can also be interpreted $96,45 \%$ variation of dependent variable can be explained by the free variable. The error value of the equation is $8.17 \%$ percentage of attack productivity.
\end{abstract}

Keywords: rice pest, rice field rat, aerial photo, percentage of attack, productivity

\section{PENDAHULUAN}

Beras sebagai salah satu makanan pokok khususnya di Indonesia, merupakan hasil pertanian yang sangat penting untuk dihasilkan. Besarnya kebutuhan akan beras menciptakan peluang besar pada bidang pertanian khususnya bagi petani padi. Namun 
kebutuhan akan beras tidak diiringi oleh peningkatan kualitas dan kuantitas beras. Menurut Kartohardjono (2009) upaya peningkatan produktivitas padi di Indonesia terdapat berbagai permasalahan dan hambatan. Hambatan yang dimaksud adalah berupa faktor abiotis dan biotis. Yang termasuk ke dalam faktor abiotis adalah kemunduran kesuburan lahan, kekeringan dan tidak menentunya perubahan iklim ataupun cuaca. Sementara itu yang termasuk ke dalam faktor biotis adalah organisme pengganggu tanaman (OPT). OPT yang menyerang tanaman padi adalah hama, penyakit, dan gulma.

Hama adalah suatu gangguan yang terjadi pada tanaman atau pada komoditas tertentu yang disebabkan oleh hewan sehingga menyebabkan terjadinya kerusakan dan kerugian secara ekonomis (Amini dkk, 2013). Salah satu hama yang dapat merugikan petani padi adalah hama tikus. Di Bali dari tahun 2010 - 2016 rata - rata serangan hama tikus mencapai 1.581,03 Ha / tahun. Pada tahun 2010 terjadi serangan hama tikus di Bali yang sangat sulit dikendalikan, akibatnya sebesar 4.044,5 Ha lahan pertanian padi di Bali terserang hama tikus. Pada tahun tersebut $2.465 \mathrm{Ha}$ lahan pertanian padi di Kabupaten Tabanan mengalami kegagalan panen akibat serangan hama tikus (BPTPH, 2017).

Hal ini pun membuat petani mengalami kerugian finansial yang tidak sedikit. Untuk mengurangi kerugian finansial akibat serangan hama yang diterima oleh petani. Pemerintah Republik Indonesia membantu mengurangi kerugian yang dialami petani dengan mengupayakan perlindungan usaha tani dalam bentuk asuransi pertanian. Menurut Pedoman Bantuan Premi Asuransi Usahatani Padi (2016) asuransi pertanian sangat penting bagi para petani untuk melindungi usaha tani. Dalam Pedoman Bantuan Premi Asuransi Usahatani Padi (2016) apabila lahan petani mengalami kerusakan $\geq 75 \%$ yang diakibatkan oleh banjir, kekeringan, dan organisme pengganggu tumbuhan (OPT) maka petani berhak mengklaim asuransi pertanian setelah petani membayar premi asuransi pertanian yang telah ditentukan.

Menurut Pedoman Asuransi Usaha Tani Padi (2016), kerusakan tanaman yang tidak dapat dikendalikan lagi, maka PPL / POPT - PHP bersama petugas penilai kerugian yang ditunjuk oleh pihak asuransi akan melakukan pemeriksaan dan perhitungan kerusakan. Perhitungan persentase kerusakan tanaman padi masih dilakukan dengan cara manual yaitu dengan pengamatan secara visual dan teknik perkiraan. Kelemahan dari metode tersebut adalah memerlukan banyak petugas dan tenaga yang lebih untuk menjangkau dan mengelilingi lahan yang di klaim. Selain pengamatan secara visual secara langsung, terdapat pula metode lain yang memungkinkan untuk diterapkan dalam menentukan luasan kerusakan padi. Metode dengan bantuan satelit dan foto udara juga memungkinkan untuk mendapatkan luasan kerusakan padi. kekurangan dari penggunaan satelit adalah penggunaannya sangat tergantung cuaca, seperti hujan, awan, dan kabut.

Sementara itu, metode pengambilan gambar dengan teknik foto udara sangat memungkinkan diterapkan pada bidang pertanian. Penggunaan drone sebagai metode dalam pengambilan gambar untuk pendugaan hasil panen sudah pernah diterapkan melalui penelitian yang dilakukan oleh Santika (2016). Penelitian ini menggabungkan teknik foto udara dengan image processing. Drone digunakan sebagai alat pengambil gambar, kemudian gambar yang didapat diolah dengan image processing Dengan kemajuan teknologi pada bidang pengolahan citra digital memberikan peluang untuk dikembangkan teknologi pengindraan jarak jauh yang kemudian dikombinasikan dengan pengolahan citra digital. Tujuan dari pelaksanaan penelitian ini adalah untuk mengetahui hubungan antara luas serangan hama tikus dengan produktivitas lahan.

\section{METODE}

\section{Tempat dan Waktu Penelitian}

Tempat dilaksanakannya proses pengambilan foto udara sebagai bahan pendugaan hasil panen padi melalui foto udara dilakukan di beberapa tempat antara lain :

a. Subak Buruan, Desa Buruan, Kecamatan Penebel, Kabupaten Tabanan

b. Subak Cangi, Desa Sembung, Kecamatan Mengwi, Kabupaten Badung

c. Subak Kuwum, Desa Kuwum, Kecamatan Mengwi, Kabupaten Badung

Penelitian ini dilaksanakan di musim tanam 1 pada bulan bulan Juli tahun 2017 - Januari tahun 2018.

\section{Bahan dan Alat Penelitian}

Bahan dari penelitian ini adalah foto udara padi berbagai varietas yang terserang hama tikus. Varietas padi yang digunakan adalah Serang, Singkil, Impari 30, dan Cigelis pada saat padi memasuki tahap masak susu (umur 81-85 hari setelah tanam) dan tahap pematangan gabah (umur 102-107 hari setelah tanam).

Alat - alat yang digunakan dalam penelitian ini antara lain alat akuisisi citra, alat pengolahan citra dan alat ukur. Alat akuisisi citra yang digunakan adalah drone Dji Phantom 4, papan skala dan papan nomor. Alat pengolahan citra yang digunakan berupa Laptop 
ASUS, dengan spesifikasi sebagai berikut: Intel core $i 5$ processor, RAM 4 GB yang dilengkapi dengan Sistem Operasi Windows 10, Software Matlab 2013 dan Software Adobe Photoshop CS 6. Alat ukur yang digunakan yaitu timbangan, lightmeter, stopwatch

\section{Pelaksanaan Penelitian}

Tahapan - tahapan yang harus dilalui untuk mengetahui hubungan antara persetase serangan hama tikus dengan produktivitas lahan adalah sebagai berikut :

\section{Pengambilan Data}

Pengambilan data dilapangan yang pertama adalah akuisisi foto udara. Akuisisi foto udara dilakukan dengan bantuan Drone Dji Phantom 4. Spesifikasi kamera drone Dji Phantom 4 dapat dilihat pada Tabel 1. Akuisisi foto udara dilakukan pada pukul 7.30 10.30 WITA dan jam 15.00 - 17.00 WITA dengan keadaan cuaca cerah intensitas cahaya 20.000 lux 60.000 lux (Bhaskara, 2015). Akuisisi dilakukan secara tegak lurus pada tanaman padi, sehingga didapat foto kanopi padi secara utuh.

\section{Tabel 1.}

Spesifikasi Kamera Drone Dji Phantom 4

\begin{tabular}{ll}
\hline Sensor & $1 / 2.3^{\prime \prime}$ CMOS \\
& $\begin{array}{l}\text { Effective pixels: } 12.4 \mathrm{M} \\
\text { LOV } 94^{\circ} 20 \mathrm{~mm}(35 \mathrm{~mm} \\
\text { format equivalent }) \mathrm{f} / 2.8 \\
\text { focus at } \infty\end{array}$ \\
& $100-1600$ (photo $)$ \\
ISO Range & $8-1 / 8000 \mathrm{~s}$ \\
Electronic Shutter & \\
Speed & $4000 \times 3000$ pixel \\
Image Size &
\end{tabular}

Data produktivitas lahan didapat dengan mengetahui hasil panen dan luas lahan sampel. Data hasil panen dan luas lahan diketahui dengan pengukuran hasil panen sampel dalam satu petak. Menurut Sinungan (2003), produktivitas adalah hasil per satuan dari suatu input (masukan). Suwarto (2011) menyebutkan pengukuran produktivitas merupakan jumlah output per unit input. Rumus perhitungan produktivitas adalah sebagai berikut :

$$
\operatorname{produktivas}\left(K g / \mathrm{m}^{2}\right)=\frac{\text { HasilPanen }(K g)}{\operatorname{LuasLahan}\left(m^{2}\right)}
$$

\section{Analisis Image Processing}

Analisis image processing dilakukan dengan bantuan software Adobe Photoshop CS6 dan Matlab 2013.
Citra yang diolah dalam proses ini adalah citra hasil akuisi foto udara. Tahapan yang harus dilalui dalam analisis image processing antara lain preprocessing citra, thresholding, morfologi citra, perhitungan skala, perhitungan persentase serangan

\section{Preprocessing Citra}

Preprocessing citra merupakan proses yang pengolahan citra yang dilakukan dengan bantuan software Adobe Photoshop CS6. Pada tahap ini citra akan diolah sesuai dengan kebutuhan untuk kemudian dialnjutkan ke tahap berikutnya. Pada tahap ini dilakukan trial and error pada citra hasil akusisi sehingga bisa didapatkan citra sesuai dengan kebutuhan program.

\section{Thresholding}

Thresholding merupakan proses untuk mengubah citra hasil preprocessing menjadi citra biner. Proses ini dilakukan trial and error terhadap kisaran level thresholding dan jenis thresholding yang diberikan. Proses ini menggunakan bantuan software Matlab 2013.

\section{Morfologi Citra}

Morfologi citra bertujuan untuk menghilangkan noise yang terdapat pada citra hasil thresholding. Pada tahap ini dilakukan trial and error pada Besaran nilai structuring elements (SE) dan tahapan operasi morfologi citra yang diberikan.

\section{Perhitungan Persentase Serangan}

Perhitungan peresentase serangan menggunakan citra biner hasil morfologi citra. Citra biner yang didapat dilakukan proses perhitungan pixel padi yang terserang hama tikus. Kemudian dilakukan perhitungan jumlah pixel luas lahan. Data jumlah pixel padi yang terserang hama tikus dan jumlah pixel luas lahan di analisis untuk mendapatkan data persentase luas serangan.

\section{Analisis Regresi}

Analisis regresi adalah metode yang digunakan untuk mengukur pengaruh variabel bebas terhadap variabel terikat. Analisis regresi dapat digunakan untuk menduga variabel terikat dengan menggunakan variabel bebas. Gujarati (2006) mendefinisikan analisis regresi adalah kajian terhadap hubungan satu variabel yang disebut sebagai variabel yang diterangkan (the explained variabel) dengan satu atau dua variabel yang menerangkan (the explanatory). Pada prinsipnya analisis regresi merupakan analisis 
untuk mencari suatu kurva yang mewakili hubungan satu set data (Luknanto, 1992).

Hubungan antara variabel bebas dan variabel terikat dapat dihubungkan dalam satu garis. Garis tersebut dapat berbentuk garis lurus (linier) ataupun berbentuk garis lengkung (logaritmik, kuadratik dan polynomial).

Hasil analisis regresi ditampilkan dalam bentuk grafik. Pembuatan grafik dilakukan dengan menggunakan bantuan software Microsoft Excel 2013. Tahap ini bertujuan untuk mengetahui seberapa erat hubungan antara persentase serangan hama tikus dengan produktivitas lahan. Analisis regresi yang digunakan dalam penelitian ini adalah regresi linier, regresi kuadratik, dan regresi polynomial. Analisis regresi logaritmik tidak dapat digunakan dalam penelitian ini, karena terdapat nilai 0 dalam data yang dimiliki.

\section{Regresi Linier}

Regresi linier digunakan menentukan fungsi linier (garis lurus) yang sesuai dengan kumpulan titik - titik data $\left(\mathrm{x}_{\mathrm{n}}, \mathrm{y}_{\mathrm{n}}\right)$ yang diketahui. Persamaan yang akan didapat melalui regresi linier adalah :

$$
\begin{aligned}
& y=a(x)+b \\
& \text { Dimana : } \\
& \mathrm{y}=\text { variabel terikat } \\
& \mathrm{x}=\text { variabel bebas } \\
& \mathrm{a}, \mathrm{b}=\text { konstanta }
\end{aligned}
$$

a(x) merupakan suatu fungsi regresi yang belum diketahui dan ingin diramalkan, sementara $b$ adalah suatu variabel acak yang menggambarkan variasi y di sekitar a(x) (Hardle, 1990).

\section{Regresi Kuadratik}

Regresi 'polynomial digunakan untuk menentukan fungsi polinomial yang paling sesuai dengan kumpulan titik data $\left(\mathrm{x}_{\mathrm{n}}, \mathrm{y}_{\mathrm{n}}\right)$ yang diketahui. Persamaan yang dihasilkan regresi polynomial pangkat 2 adalah sebagai berikut :

$$
\begin{gathered}
\mathrm{y}=\mathrm{a}_{0}+\mathrm{a}_{1} \mathrm{x}+\mathrm{a}_{2} \mathrm{x}^{2} \ldots \ldots \ldots . . . . . \\
\\
\text { Dimana }: \\
\mathrm{y}=\text { variabel terikat } \\
\mathrm{x}=\text { variabel bebas } \\
\mathrm{a}, \mathrm{b}=\text { konstanta }
\end{gathered}
$$

Grafik yang dihasilkan pada analisis regresi polinomial pangkat 2 adalah berbentuk parabola.

\section{Regresi Polynomial Pangkat 3}

Regresi polynomial merupakan salah satu analisis matematika yang melibatkan jumlah perkalian pangkat dalam satu variabel dengan koefisien. Pada penelitian ini menggunakan regresi polinomial pangkat 3 Persamaan yang dihasilkan regresi polynomial pangkat 3 adalah sebagai berikut : $\mathrm{y}=\mathrm{a}_{0}+\mathrm{a}_{1} \mathrm{x}+\mathrm{a}_{2} \mathrm{x}^{2}+\mathrm{a}_{3} \mathrm{x}^{3}$

$$
\begin{gathered}
\text { Dimana : } \\
\mathrm{y}=\text { variabel terikat } \\
\mathrm{x}=\text { variabel bebas } \\
\mathrm{a}, \mathrm{b}=\text { konstanta }
\end{gathered}
$$

Bentuk grafik yang dihasilkan analisis regresi polynomial pangkat 3 adalah grafik pangkat 3 .

\section{Validasi}

Tujuan dari validasi adalah untuk mengetahui pesentase nilai error yang diberikan oleh aplikasi dalam menduga hasil panen. Dalam penelitian ini data yang di validasi adalah data hasil panenpanen padi. Persamaan validasi yang dapat digunakan adalah sebagai berikut:

$\mathrm{RMSE}=\sqrt{\frac{\sum_{\mathrm{i}=1}^{\mathrm{n}}\left(\mathrm{x}_{\text {pengukuran }}-\mathrm{x}_{\text {pendugaan }}\right)^{2}}{\mathrm{n}}} x 100 \%$

Validasi data diukur dengan menggunakan metode RMSE (Root Mean Squer Error). Menurut Hakim (2011), jika nilai RMSE kurang atau sama dengan $10 \%$ maka aplikasi tersebut dapat dikatakan akurat.

\section{Akurasi Pendugaan}

Akurasi menunjukkan kedekatan nilai hasil pengukuran atau percobaan yang dilakukan dengan nilai yang sebenarnya. Hal ini berkaitan dengan tingkat penyimpangan dari suatu hasil pengukuran atau percobaan terhadap nilai yang sebenarnya. Nilai akurasi dapat dihitung dengan mengetahui nilai kesalahan pendugaan. Semakin kecil nilai kesalahan pendugaan maka semakin akurat pendugaan yang dibuat. Adapun perhitungan kesalahan pendugaan adalah sebagai berikut:

Akurasi Pendugaan $(\%)=100 \%-$ RMSE

\section{HASIL DAN PEMBAHASAN}

\section{Pengambilan Data}

Pengambilan data dilapangan tahap yang pertama adalah akuisisi foto udara. Akuisisi foto udara dilakukan dengan bantuan Drone Dji Phantom 4. Akuisisi foto udara dilakukan pada pukul 7.30 - 
10.30 WITA dan jam 15.00 - 17.00 WITA dengan keadaan cuaca cerah intensitas cahaya 20.000 lux 60.000 lux (Bhaskara, 2015). Kisaran suterspeed yang digunakan adalah 200 - 640 dengan ISO sebesar 100 . Kecepatan drone yang digunakan adalah $1,9 \mathrm{~m} / \mathrm{s}$ dengan interval pengambilan gambar adalah 3 detik. Citra hasil akuisisi foto udara kemudian akan diolah untuk mendapatkan data persentase serangan. Setelah dilakukan akuisisi foto udara kemudian dilakukan pengukuran hasil panen sampel dalam satu petak lahan. Data hasil panen panen digunakan untuk menghitung produktivitas lahan.

\section{Analisis Image Processing}

Analisis Image Processing yang dilakukan dalam penelitian ini bertujuan untuk mendapatkan persentase luas serangan hama tikus. Analisis image processing dalam penelitian ini antara lain :

\section{Preprocessing Citra}

Preprocessing citra yang dilakukan dalam penelitian ini adalah normalisasi warna citra, mozaiking citra, dan resize citra. Normalisasi warna citra merupakan proses untuk meningkatkan kualitas citra agar sesuai dengan kebutuhan. Normalisasi warna citra dilakukan dengan meningkatkan nilai kontas berkisar +10 sampai +80. Mozaiking citra adalah proses penggabungan beberapa citra yang saling overlapping sehingga menghasilkan sebuah citra baru yang menunjukkan petak sawah secara utuh dan menyatu. Proses normalisasi warna citra dan mozaiking citra dilakukan dengan bantuan software Adobe Photoshop CS6. Resize citra bertujuan untuk memberkecil ukuran citra sehingga memori yang diperlukan lebih sedikit dan proses dapat berjalan lebih cepat.

\section{Thresholding}

Proses thresholding merupakan proses merubah citra RGB hasil preprocessing dirubah menjadi citra biner. Dalam tahap ini pixel padi yang terserang hama tikus akan dirubah menjadi hitam, sedangkan pixel padi yang tidak terserang hama tikus berubah menjadi putih. Citra hasil thresholding dapat dilihat pada Gambar 1.

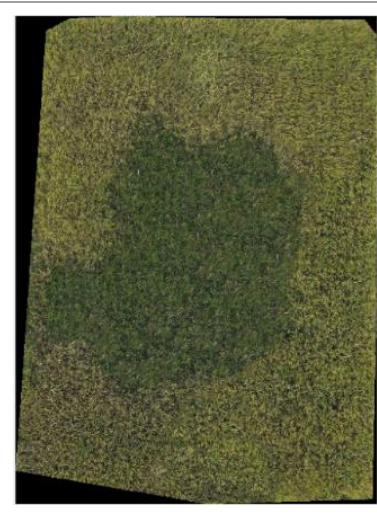

A

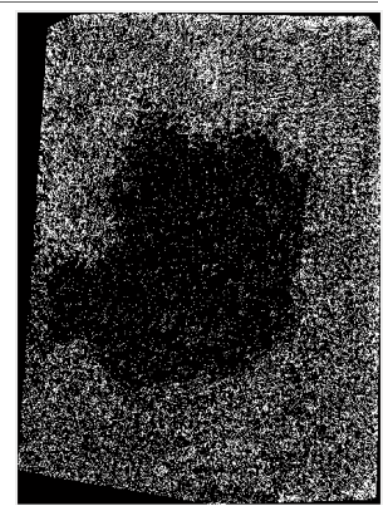

$\mathrm{B}$
Gambar 1. Citra Hasil Thresholding, (A) Sebelum Thresholding, (B) Setelah Thresholding

\section{Morfologi Cita}

Morfologi citra merupakan proses yang bertujuan untuk memperjelas citra hasil thresholding. Jemis morfologi citra yang digunakan dalam penelitian ini antara lain : closing, dilasi, erosi, dan opening. Closing digunakan untuk menutup celah atau citra hitam yang terdapat diantara citra putih. Dilasi bertujuan agar citra berwarna putih yang renggang dapat semakin rapat dan menyatu. Dilasi bertujuan untuk memperbesar batas - batas objek sehingga objek akan semakin besar dan lubang yang terdapat ditengah objek akan mengecil. Erosi bertujuan untuk memperjelas objek dengan mempersempit batas batas objek. Opening merupakan penggabungan proses erosi dan dilasi proses memperjelas objek dengan menghilangkan objek kecil yang terdapat dalam citra. Closing meripakan penggabungan proses dilasi dan erosi, akan memperjelas objek dengan cara menutup lubang kecil yang terletak ditengah objek. Citra hasil morfologi dapat dilihat pada Gambar 2.

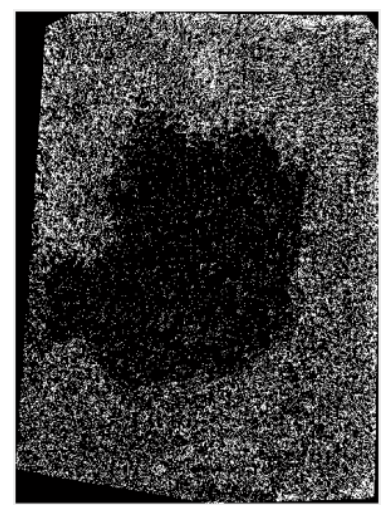

A

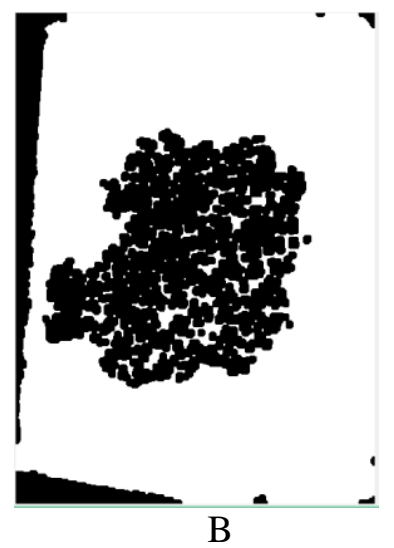

B
Gambar 2. Citra Hasil Morfologi, (A) Sebelum Morfologi, (B) Setelah Morfologi 


\section{Perhitungan Persentase Serangan}

Perhitungan peresentase serangan didapat dengan menghitung jumlah pixel yang terserang hama tikus dan jumlah pixel luas lahan. Dalam citra biner hasil morfologi, pixel yang berwarna hitam menunjukkan tanaman padi yang terserang hama dan pixel yang berwarna putih menunjukkan tanaman padi yang tidak terserang hama tikus. Jumlah pixel hitam dibagi jumlah pixel untuk kemudian dikalikan dengan 100\% sehingga akan menghasilkan persentase serangan. Data persentase serangan dan produktivitas lahan dapat dilihat pada Tabel 2.

\section{Tabel 2.}

Data Persentase Serangan dan Produktivitas

\begin{tabular}{lrr}
\hline \multicolumn{1}{c}{ Keterangan } & $\begin{array}{c}\text { Persentase } \\
\text { Serangan }(\%)\end{array}$ & $\begin{array}{c}\text { Produktivitas } \\
\text { Lahan }\left(\mathrm{Kg} / \mathrm{m}^{2}\right)\end{array}$ \\
\hline 100\% serangan & 100 & 0,00 \\
Lahan 11 & 96,20 & 0,04 \\
Lahan 9 & 84,74 & 0,03 \\
Lahan 8 & 70,57 & 0,05 \\
Lahan 5 & 59,43 & 0,08 \\
Lahan 4 & 40,47 & 0,09 \\
Lahan 1 & 24,14 & 0,28 \\
Lahan 13 & 17,67 & 0,34 \\
Lahan 14 & 7,98 & 0,37 \\
0\% serangan & 0 & 0,66 \\
\hline
\end{tabular}

\section{Analisis Regresi}

Analisis regresi adalah salah satu analisis statistik yang bertujuan untuk memperoleh persamaan kurva pendekatan dari titik - titik data yang diketahui. Dalam penenelitian ini menggunakan tiga jenis analisis regresi, antara lain regresi linier, regresi kuadratik dan regresi polynomial.

\section{Regresi Linier}

Dalam penenelitian ini grafik dan persamaan yang didapat dalam analisis regresi linier dapat dilihat pada Gambar 3.

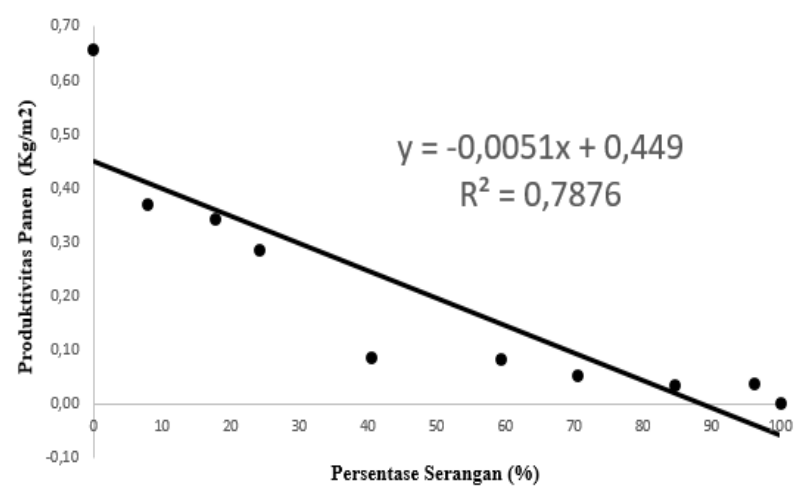

Gambar 3. Grafik Analisis Regresi Linier
Berdasarkan Gambar 3. dapat diketahui bahwa persamaan analisis regresi yang didapat dalam penelitian ini adalah $\mathrm{y}=-0,0051 \mathrm{x}+0,449$ dengan koefisien determinasi dari kedua variabel adalah 0,7876 atau dapat pula diartikan $78,76 \%$ variasi dari variabel terikat dapat dijelaskan oleh variabel bebas.

\section{Regresi Kuadratik}

Dalam penenelitian ini grafik dan persamaan yang didapat dalam analisis regresi kuadratik dapat dilihat pada Gambar 4.

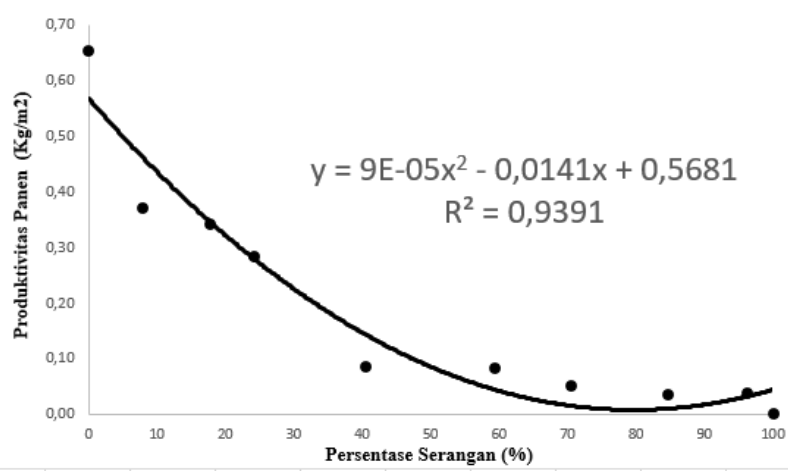

Gambar 4. Grafik Analisis Regresi Kuadratik

Berdasarkan Gambar 4. dapat diketahui bahwa persamaan analisis regresi yang didapat dalam penelitian ini adalah $y=0,0009 x^{2}-0,0141 x+0,5681$ dengan koefisien determinasi dari kedua variabel adalah 0,9391 atau dapat pula diartikan 93,91\% variasi dari variabel terikat dapat dijelaskan oleh variabel bebas.

\section{Regresi Polinomial}

Dalam penenelitian ini regresi polinomial yang digunakan adalah regresi polinomial ordo 3. Grafik dan persamaan yang didapat dalam analisis regresi polinomial dapat dilihat pada Gambar 5.

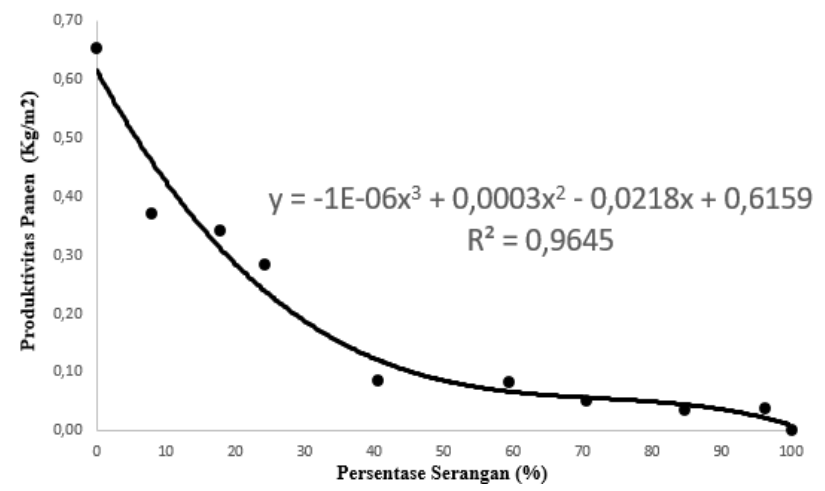

Gambar 5. Grafik Analisis Regresi Polinomial

Berdasarkan Gambar 5. dapat diketahui bahwa persamaan analisis regresi polinomial ordo 3 didapat 
dalam penelitian ini adalah $y=-0,00001 x^{3}+0,0003 x^{2}$ $-0,0218 x+0,6159$ dengan koefisien determinasi dari kedua variabel adalah 0,9645 atau dapat pula diartikan $96,45 \%$ variasi dari variabel terikat dapat dijelaskan oleh variabel bebas.

Setelah dilakukan tiga jenis analisis regresi, yaitu regresi linier, regresi kuadratik, dan regresi polinominal. Ketiga jenis analisis regresi menghasilkan persamaan dan koefisien determinasi yang berbeda - beda. Data persamaan ketiga analisis regresi dapat dilihat pada Tabel 3.

Tabel 3.

Hasil Analisis Regresi

\begin{tabular}{llc}
\multicolumn{1}{c}{ Regresi } & \multicolumn{1}{c}{ Persamaan } & \multicolumn{1}{c}{$\mathrm{R}^{2}$} \\
\hline Linier & $\mathrm{y}=-0,0051 \mathrm{x}+0,449$ & 0,7876 \\
Kuadratik & $\mathrm{y}=0,0009 \mathrm{x}^{2}-0,0141 \mathrm{x}+$ & 0,9391 \\
& 0,5681 & \\
Polinomial & $\mathrm{y}=-1.10^{-6} \mathrm{x}^{3}+0,0003 \mathrm{x}^{2}-$ & 0,9645 \\
& $0,0218 \mathrm{x}+0,6159$ & \\
\hline
\end{tabular}

Berdasarkan Tabel 3, dapat diketahui bahwa persamaan yang dihasilkan dalam analisis regresi polinomial merupakan persamaan yang terbaik. Dengan koefisien determinasi sebesar 0,9645, dapat pula diartikan $96,45 \%$ variasi dari variabel terikat dapat dijelaskan oleh variabel bebas.

\section{Validasi}

Validasi merupakan proses untuk mengetahui seberapa akurat persamaan pendugaan untuk menduga hasil panen yang didapat. Keakuratan persamaan pendugaan dapat diketahui dengan membandingkan hasil pendugaan dengan hasil pengukuran dilapangan. Keakuratan pendugaan perogram dapat dihitung dengan menggunakan metode RMSE. Dengan metode RMSE program dapat dikatakan akurat bila error kurang dari sama dengan 10\% (Hakim, 2010). Perbedaan hasil pendugaan dengan hasil panen tanaman padi dapat ditunjukan pada Tabel 4.

\section{Tabel 4.}

Nilai Error Pendugaan Hasil Panen

\begin{tabular}{lrrr}
\hline \multirow{2}{*}{ Lahan } & \multicolumn{2}{c}{ Hasil Panen $(\mathrm{Kg})$} & RMSE \\
\cline { 2 - 3 } & Pengukuran & Pendugaan & $(\%)$ \\
\hline Lahan 12 & 158 & 163,41 & \\
Lahan 2 & 88 & 88,32 & \\
Lahan 7 & 123 & 137,34 & 8,17 \\
Lahan 10 & 40 & 49,30 & \\
Lahan 6 & 27 & 26,11 & \\
Lahan 3 & 36 & 39,92 & \\
\hline
\end{tabular}

Akurasi merupakan kesamaan atau kedekatan hasil pengukuran dengan hasil sesungguhnya. Nilai akurasi program dapat diketahui dengan mengurangi nilai RMSE dengan $100 \%$. Sehingga didapat nilai akurasi program sebesar $91,83 \%$. Semakin besar nilai akurasi maka semakin akurat program tersebut.

\section{KESIMPULAN DAN SARAN}

\section{Kesimpulan}

Berdasarkan penelitian yang telah dilakukan maka dapat disimpulkan sebagai berikut: Persamaan hubungan antara persentase luasan serangan dengan produktivitas lahan terbaik adalah analisis regresi polynomial ordo 3 dengan $y=-1.10^{-6} x^{3}+0,0003 x^{2}-$ $0,0218 x+0,6159$ dan koefisien determinasi antara keduanya sebesar 0,9645 dengan nilai error sebesar $8,17 \%$.

\section{Saran}

Dalam melakukan pendugaan luasan serangan hama tikus harus memperhatikan strandar operasional prosedur (SOP) program. Untuk pengembangan program pendugaan luasan serangan hama tikus akan lebih baik jika dilakukan dengan peralatan dengan spesifikasi yang lebih tinggi. Sehingga akan menghasilkan citra dengan detail yang lebih baik. Selain itu, pengembangan aplikasi dapat pula dilakukan untuk berbagai jenis hama yang menyerang tanaman padi.

\section{DAFTAR PUSTAKA}

Arafah. 2009. Pedoman Teknis Perbaikan Kesuburan Lahan Sawah Berbasis Jerami. Gramedia. Jakarta.

Balai Perlindungan Tanaman Pangan dan Hortikultura. 2017. Luas Tambah Serangan 5 OPT Utama Tanaman Padi Di Bali Tahun 2010 - 2017. Gianyar.

Bhaskara, P., Wijaya, I.M.A.S., Setiyo, Y. 2015. Pengembangan Algoritma Image Processing Untuk Menduga Hasil Panen Padi. Jurnal BETA (Biosisten dan Teknik Pertanian), 3(1).

Direktorat Jendral Prasarana dan Sarana Pertanian. 2016. Pedoman Bantuan Premi Asuransi Usahatani Padi. http://psp.pertanian.go.id/assets/file/2016/PE DUM20AUTP201520Jan202016.pdf (diakses pada tanggal 19 Mei 2017)

\section{Akurasi}


Hadi, Sutrisno. 2004. Analisis regresi. Andi Offset. Yogyakarta.

Hakim, A.,R. 2010. Perancangan Sistem Informasi Pengukuran Konduktivitas Hidraulik Tidak Jenih Tanah dengan Sensor Tensiometer dan Higrometer Digital. Skripsi. Jurusan Teknik Elektro Fakultas Teknik Universitas Jember

Harahap, I.S., Tjahjono, B. 2003. Pengendalian Hama Penyakit. Penebar Swadaya. Jakarta.

Hardle, Wolfgang. 1990. Smoothing Techniques With Implementation in S. Springer Verlag. New York.

Kartohardjono, A., Kertoseputro, D., dan Suryana, T. 2009. Hama Padi Potensial dan Pengendaliannya.http://www.litbang.pertanian .go.id/special/padi/ bbpadi_2009_itp_16.pdf (diakses pada tanggal 20 Mei 2017)

Luknanto, Djoko. 1992. Regresi Kuadrat Terkecil Untuk Kalibrasi Bangunan Ukur Debit. Universitas Gadjah Mada. Yogyakarta.

Priyambodo. 1995. Pengendalian Hama Tikus Terpadu. Penebar Swadaya. Jakarta.

Santika, P., Wijaya, I.M.A.S., Gunadnya, I.B.P. 2016. Kualitas Foto Udara Pada Berbagai Ketinggian. Jurnal BETA (Biosisten dan Teknik Pertanian), 4(2), 76 - 80.

Sinungan, Muchdarsyah. 2003. Produktivitas Apa dan Bagaimana. Bumi Aksara. Jakarta.

Suwarto. 2011. Kelembagaan Lahan dan Tenaga Kerja Pada Usahatani Suatu Analisa pada Lahan Kering. UNS Press. Surakarta. 